\title{
Human Activities and Climate Variability Affecting Inland Water Surface Area in a High Latitude River Basin
}

\author{
Liwen Chen ${ }^{1,2}$, Guangxin Zhang ${ }^{2, *}, Y$. Jun $\mathrm{Xu}^{3}{ }^{3}$, Shengbo Chen ${ }^{1}$, Yanfeng $\mathrm{Wu}^{2}{ }^{2}$, \\ Zongting Gao ${ }^{4,5}$ and Haiyang $\mathrm{Yu}^{1}$ \\ 1 College of Geo-Exploration Science and Technology, Jilin University, Changchun 130026, China; \\ chenliwen86@126.com (L.C.); chensb@jlu.edu.cn (S.C.); yuhaiyang2017@126.com (H.Y.) \\ 2 Northeast Institute of Agroecology and Geography, Chinese Academy of Sciences, \\ Changchun 130102, China; wuyanfeng@iga.ac.cn \\ 3 School of Renewable Natural Resources, Louisiana State University Agricultural Center, Baton Rouge, \\ LA 70803, USA; yjxu@lsu.edu \\ 4 Jilin Provincial Key Laboratory of Changbai Mountain Meteorology \& Climate Change, \\ Changchun 130062, China; ztgtq@sina.com \\ 5 Institute of Meteorological Sciences of Jilin Province, Changchun 130062, China \\ * Correspondence: zhgx@iga.ac.cn; Tel.: +86-0431-8554-2210; Fax: +86-0431-8554-2298
}

Received: 10 December 2019; Accepted: 29 January 2020; Published: 31 January 2020

check for updates

\begin{abstract}
Spatiotemporal changes in the surface area of inland water bodies have important implications in regional water resources, flood control, and drought hazard prediction. Although inland water bodies have been investigated intensively, few studies have looked at the effect of human activities and climate variability on surface area of inland waters at a larger scale over time and space. In this study, we used MODIS (MOD13Q1) images to determine water surface area extent at $250 \mathrm{~m}$ spatial resolution. We then applied this algorithm with MOD13Q1 images taken at 16-day intervals from 2000 to 2018 to a large river basin in China's northeast high latitude region with dense stream network and abundant wetlands to investigate spatiotemporal distribution and dynamics of inland water bodies. The study identified 209 ponds, lakes, and reservoirs with an average total surface area of $2080 \mathrm{~km}^{2}$ in the past 19 years. The total water surface area fluctuated largely from $942 \mathrm{~km}^{2}$ to $5169 \mathrm{~km}^{2}$, corresponding to rainfall intensity and flood. We found that the total water surface area in this high latitude river basin showed an increasing trend during the study period, while the annual precipitation amount in the river basin also had an increasing trend concurrently. Precipitation and irrigation significantly contributed to the monthly change of water surface area, which reached the highest during June and August. The increase of water surface area was significant in the lower basin floodplain region, where agricultural irrigation using groundwater for rice production has progressed. Four nationally important wetland preserves (Zhalong, Xianghai, Momoge, and Chagan Lake) in the river basin made up nearly $50 \%$ of the basin's total water surface area, of which Zhalong, Xianghai, and Momoge are designated by The Ramsar Convention as wetland sites of international importance. Seasonally, these water bodies reached their maximal surface area in August, when both the monsoon weather and agricultural discharge prevailed. This study demonstrates that water surface area in a high latitude river basin is affected by both human activities and climate variation, implying that high latitude regions will likely experience more changes in surface water distribution as global climate change continues and agriculture becomes intensified.
\end{abstract}

Keywords: surface water area; wetlands; Anthropocene; global climate change; satellite remote sensing; MODIS; Nenjiang River Basin 


\section{Introduction}

Inland surface water accounts for only a small portion of the entire hydrosphere on Earth [1-3]. However, it plays a vital role in sustaining aquatic and terrestrial lives, including humanity, as it provides drinking water, agricultural irrigation, industrial use, fisheries, and wildlife habitats [4]. These waterbodies are also sites of active biogeochemical processing [2] and can play a critical role in aquatic-atmospheric carbon exchange [5-8]. Furthermore, surface water areal extent is an important indicator of flood and drought. Global climate change can alter the availability and distribution of water resources, thus increasing pressure on freshwater supplies and causing water shortages for human use and socio-economic development $[9,10]$. Reliable assessment of surface water storage and understanding the factors affecting its fluctuation is key to water resources management [11,12]. A recently developed global data of inland water bodies suggested that there were approximately 117 million lakes on Earth with a surface area of about 5 million $\mathrm{km}^{2}$ or $\sim 3.7 \%$ of the Earth's non-glaciated land area [13]. Dynamic change of these water bodies could have important impacts on regional floods and/or droughts, which pose great challenges all over the world [14]. Although the knowledge is well recognized, our understanding of water body dynamic changes over large space and time scales is rather limited. Especially, little is known about the effect of human activities and global climate change on inland water at large space and time scales, knowledge that can be crucial for regional water resources and hydrological disaster planning and management.

Over the past few decades, remote sensing technology has advanced significantly, providing frequent image coverage over the Earth's surface $[12,15,16]$. Together with computational and software advancement, satellite image data can help facilitate large-scale assessment on the dynamics of surface water bodies [17]. The United States National Aeronautics and Space Administration (NASA) provides MODIS Land data products that can be used to track changes in surface water. The products include MOD13Q1 and MOD44W data; the former is a 16-day $250 \mathrm{~m}$ vegetation index product, respectively [18], while the latter is the water surface product data of MODIS with a global coverage and a spatial resolution of $250 \mathrm{~m}$ with annual datasets [19]. In the past, many studies used Landsat data to estimate long-term water body changes because of the dataset's high spatial resolution [15]. When compared with Landsat data, MODIS has higher temporal resolution, and the Normalized Difference Vegetation Index (NDVI) data derived from MOD13Q1 can be applied to extracting information on water bodies [20]. Using MOD13Q1 data, more detailed analysis can be achieved for large-scale changes in water surface area over both seasonal and interannual scales.

Very recently, two studies [21,22] used MODIS images to assess characteristics of large-scale inland water bodies over a decadal time span. These studies demonstrated the great usefulness of MODIS images in investigating inland water bodies at large geographical scales with different climatic and terrain conditions. However, the studies almost solely focused on the technical aspects of data retrieving, image processing, and mapping accuracy, without analyzing which factors may have influenced the changes in water bodies. In the recent decade, it has been increasingly recognized that global climate change is expected to have stronger effects on water resources in higher latitude regions. These regions are snow- and/or glacial-dominated and, hence, will be more strongly affected by a warming climate [23-25]. The warming can in turn lead to more human activities in higher-latitude regions, such as agricultural production, dam construction for irrigation and flood control, and urbanization, as already evidenced by the large areal conversion of wetlands to agricultural cropland in North China [26,27]. It is not clear how a combination of future global climate change and human activity would impact water surface area in the world's higher-latitude regions. Such information is needed for researchers, practitioners, and policy makers to identify critical needs in water resources and develop effective sustainable management strategies and plans.

With this in mind, this study aimed to investigate the effect of human activity and climate variability on inland water bodies in a higher latitude region. Our initial hypothesis was that both climate change and human activity in this region would increase water surface area, and that the contribution of human activity to this would be greater. To test this hypothesis, we used a large 
river basin in China's far northeast cold region, the Nenjiang River Basin (NRB), as a case study to understand how these two factors can affect spatiotemporal dynamics of inland water surface area. Specifically, the study was to: 1) determine the surface water area of all water bodies that were greater than $1 \mathrm{~km}^{2}$ over the period from 2000 to 2018 in the Nenjiang River Basin using MOD13Q1 images; 2) analyze spatiotemporal variation patterns of these water bodies over the past 19 years; and 3) investigate the influence of human activity on water surface area and the response of water bodies with different area sizes to climate variability.

\section{Methods}

\subsection{Study Area}

The Nenjiang River flows southward for $1370 \mathrm{~km}$ with a total drainage area of $297,000 \mathrm{~km}^{2}$. Geographically, the river basin covers the area of latitude $43.6-51.2^{\circ} \mathrm{N}$ and longitude $118.4-128.9^{\circ} \mathrm{E}$ (Figure 1) and is among China's high latitude regions with many wetlands and open water bodies. In climate change studies, surface water plays a vital role in securing the region's agricultural and domestic water uses, as well as maintaining ecological integrity [28,29]. The Nenjiang River Basin is located in a semi-arid region, which belongs to the temperate continental monsoon climate, with cold and dry winters, warm and rainy summers, dry springs, and rapid cooling autumns. Based on the topography and river network, the NRB can be divided into upper, middle, and lower sub-basins. The upper NRB is mountainous, with long narrow river valleys covered by forests. The middle NRB presents a transitional zone from hills to floodplains, with pastureland and increased agricultural cropping. The lower NRB is composed of floodplains with braided channels and widespread wetland areas, including the Zhalong wetland and Xianghai wetland, listed on the international list of important wetlands, as well as two national nature preserves; the Momoge wetland and Chagan Lake wetland preserves.

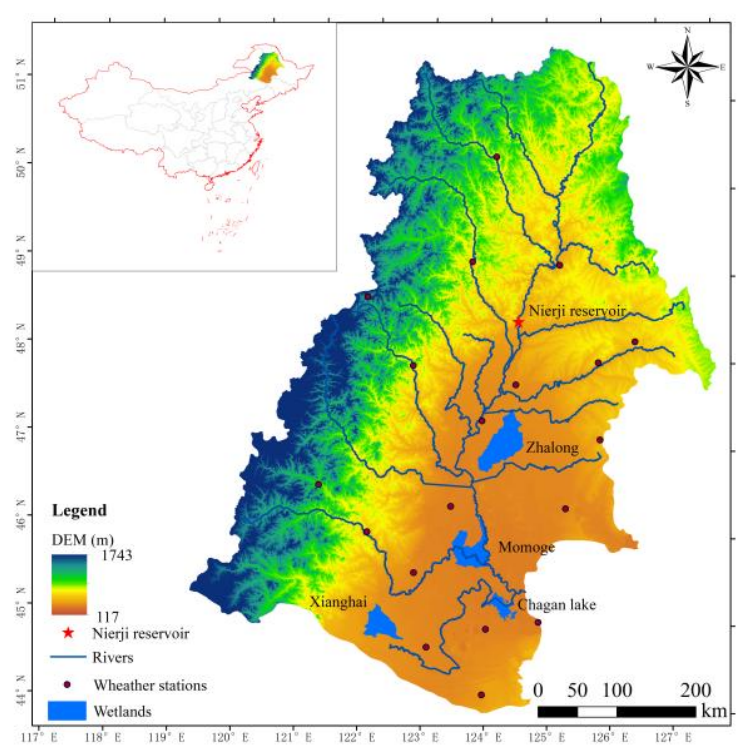

(a)

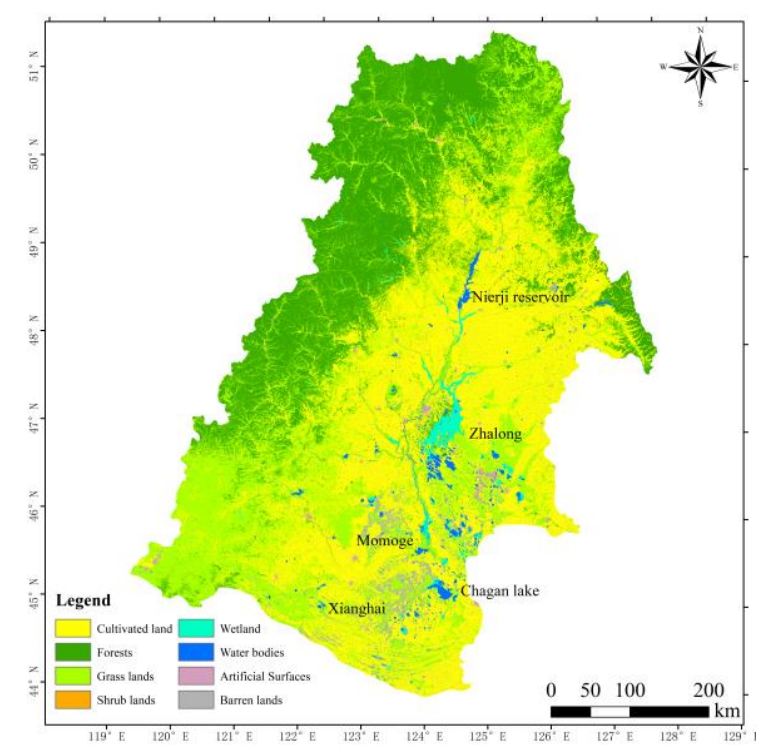

(b)

Figure 1. (a) Geographical location and (b) land use of the Nenjiang River Basin, Northeast China, with four large open water bodies, including the Zhalong wetland, Xianghai wetland, Momoge wetland, and Chagan Lake.

From 1956 to 2010, the annual average temperature in the NRB was about $2.1^{\circ} \mathrm{C}$ and the annual average precipitation was $455 \mathrm{~mm}$. About $70 \%-80 \%$ of the annual precipitation occurred during the summer, causing floods in the season $[30,31]$. The NRB is an important commodity grain base in China because of its rich cultivated land resources, good matching of water and soil, and suitable 
photothermal conditions. The main land use types of the NRB are forest (35.44\%) and farmland (30.88\%). The remaining area of the NRB is covered by grassland (20.08\%) and wetlands (6.25\%) [10]. In 2010, the cultivated land area was $81,140 \mathrm{~km}^{2}$, or 0.51 ha per capita; far higher than the national average. The effective irrigated area of farmland was $22,273 \mathrm{~km}^{2}$, of which the grain area was $20,436 \mathrm{~km}^{2}$. The actual irrigation area was $17,335 \mathrm{~km}^{2}$, of which $4345 \mathrm{~km}^{2}$ were paddy fields. The NRB is also an important ecological protection area for the many important wetland preserves. In 2005, a dam, named Nierji dam, was built across the Nenjiang River at Nierji Basin, approximately $585 \mathrm{~km}$ from its outlet, creating a large reservoir. This dam is the only flow control on the mainstream of the Nenjiang River and is an important flood control project for the downstream basin. The Nierji dam has a total storage capacity of $86.1 \times 10^{8} \mathrm{~m}^{3}$ and the area of the river basin above the dam site is $66,400 \mathrm{~km}^{2}$, accounting for $22.4 \%$ of the total area of the Nenjiang River Basin.

\subsection{MODIS Image Collection}

In this study, we used MODIS satellite images (MOD13Q1 products), acquired during the period of late April-late September from 2000 to 2018. The selection excluded the period of snow and ice cover during the winters. Four scenes of the MOD13Q1 data were needed to cover the study area (Figure 1) and, for the 19 study years, a total of 836 scenes were used. The MOD44W product data were available from 2000 to 2015 and were downloaded from NASA's Level-1 and Atmosphere Archive and Distribution System (LAADS) [32]. In this study, 64 scenes of MOD44W were collected for validation.

\subsection{Ancillary Data}

Daily precipitation, maximum and minimum temperature, wind speed, and sunshine hour data of 16 meteorological stations in the Nenjiang River Basin were gathered for 2000-2018 from the China Meteorological Data Sharing System [33] (http://data.cma.cn/). Potential evapotranspiration (PET) was calculated using the Penman-Monteith equation [34]. The observed meteorological data and PET were used to explore the relationship between the water surface extent and meteorological factors.

We used water withdrawal data downloaded from the global gridded monthly sectoral water use dataset developed by Huang et al. [35]. The dataset covered the period from 1971 to 2010. The gridded water withdrawal dataset was freely available and was used to verify the accuracy of water collection in spatial and temporal analysis. In this study, we used the database associated with precipitation and evaporation data to quantify the impact of global climate change on the water surface area of the NRB. We also used the information on water use of irrigation, domestic, electricity generation, livestock, mining, and manufacturing sectors to reflect the effect of human activity on water resources in the basin.

\subsection{Image Analysis}

In this study, the MOD13Q1 data were first processed by the MODIS Reprojection Tool (MRT), including splicing and projection [32]. The remote sensing images were then further processed by an Interactive Data Language (IDL) batch program to delineate water body using a threshold value derived from the MOD13Q1 data. Specifically, NDVI extracted from MOD13Q1 was processed by MRT. Based on point selection statistics, the NDVI values for river and lake water bodies were -0.3 and the NDVI values for other areas, such as vegetation or bare land, were greater than 0 . Therefore, the threshold value was set to 0 for extracting the water body, i.e., the area with an NDVI value of less than 0 was classified as a water body, while the area with an NDVI value of greater than 0 was classified as a non-water body. The second step was done by delineating the preliminary water boundary by using this threshold. The third step acquired the annual water surface mask, which is used to eliminate other interfering information that may affect the final lake water surface mapping. 
We calculated the drowning frequency (WIF) of each pixel, with respect to the total time series, by superposition of multiple maps, using the following formula [14,36]:

$$
W I F=\frac{\sum_{i=1}^{N}(\varepsilon i=1)}{\mathrm{N}} * 100 \%
$$

where $N$ is the number of total time series water surface area maps, $I$ is the corresponding $i_{\text {th }}$ water surface area map, and $\varepsilon_{i}$ is the corresponding pixel value of the $i_{t h}$ water map. According to the continuous MODIS time series, the WIF of the NRB was calculated and divided it into four classes: $0 \%-25 \%, 25 \%-50 \%, 50 \%-75 \%, 75 \%-100 \%[37,38]$.

\subsection{Statistical Analysis}

Regression analysis was used to determine the relations of water surface area with precipitation and evaporation. The coefficient of variation of seasonal and annual surface areas were calculated to assess areal fluctuation of water bodies. The statistical analyses were performed with Microsoft Excel 2016 (Microsoft Corporation, Redmond, WA, USA). The boxplot diagram of annual and monthly water area variation was plotted using Origin Lab Pro 2019 (Origin Lab Corporation, Northampton, MA, USA). Analysis of variance (ANOVA) and Fisher's least significant difference (LSD) tests [39] were performed to detect significant levels for the correlation between two datasets and datasets change trend, such as the extracted water surface area and reference data.

Water surface area alteration was highly variable across the Nenjiang River Basin, as indicated by the climate variability and anthropogenic activities. In this study, we aggregated precipitation and evaporation as climate variability and aggregated irrigation, domestic, electricity generation, livestock, mining, and manufacturing as anthropogenic activities. According to the definitions by the United States Geological Survey (USGS) and the United Nation Food and Agriculture Organization (FAO), domestic water withdrawal here represents the water use for indoor household purposes, outdoor purposes, and for industries and urban agricultures that are connected to the municipal system [35]. Boosted regression tree (BRT) models [40,41] were used to investigate the relationship of water surface area with the climatic and anthropogenic factors in the NRB. BRT is a machine learning method, which adds many simple single regression trees and takes the average value to form a collective model to improve prediction performance [40-42]. The BRT models were downloaded from https://cran.r-project.org/web/packages/gbm/index.html and were performed in R 3.6.2 for Windows (R Foundation for Statistical Computing, Vienna, Austria).

\subsection{Validation}

The MOD44W data were used as reference data to validate the water surface area extracting results (Figure 2). In this study, we downloaded all MOD44W data of the NRB from 2000 to 2015. It was used to verify the water surface area extracted by the NDVI threshold method in MOD13Q1 product data. The water surface area extracted by the NDVI threshold method was synthesized into 16 annual water areas from 2000 to 2015 . Two sets of annual water area data in NRB were regressed, and $R^{2}$ was 0.93. Hence, the extracted and reference data showed a good fit and can be used to quantitatively assess surface area variation in the NRB.

In summary, data analysis of this study included three major steps: (1) extraction and verification of water surface area; (2) correlation analysis of water surface area and meteorological elements; and (3) analysis of contribution of driving water surface area dynamic change by the BRT model. The approach is schematically shown in Figure 3. 


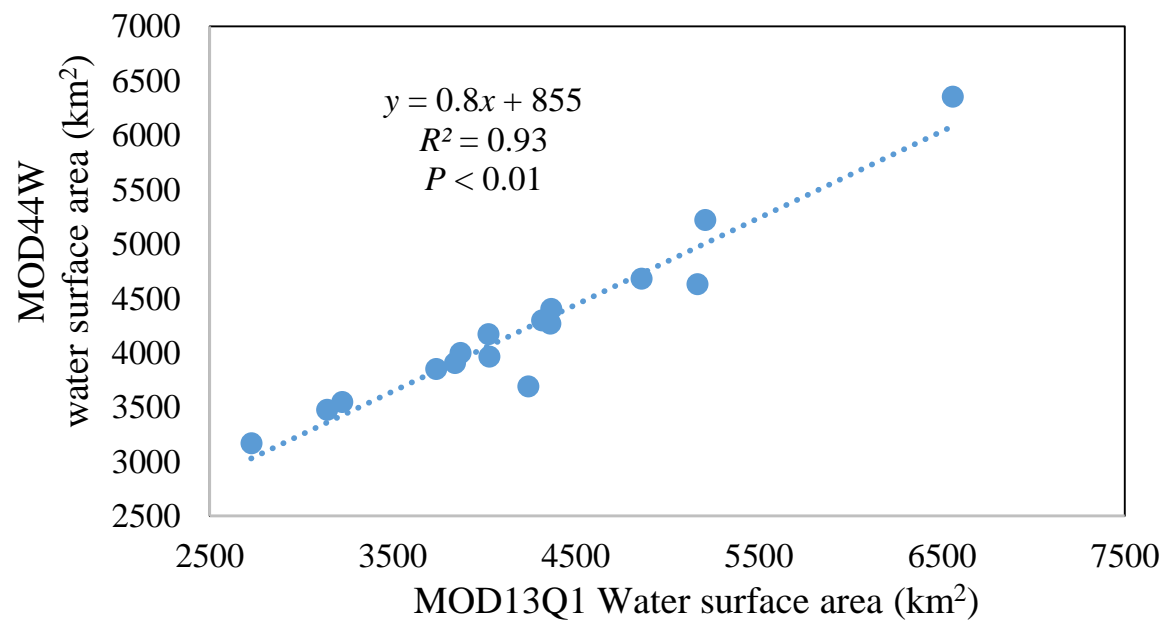

Figure 2. Water surface area correlation diagram obtained from MOD44W and MOD13Q1 data.

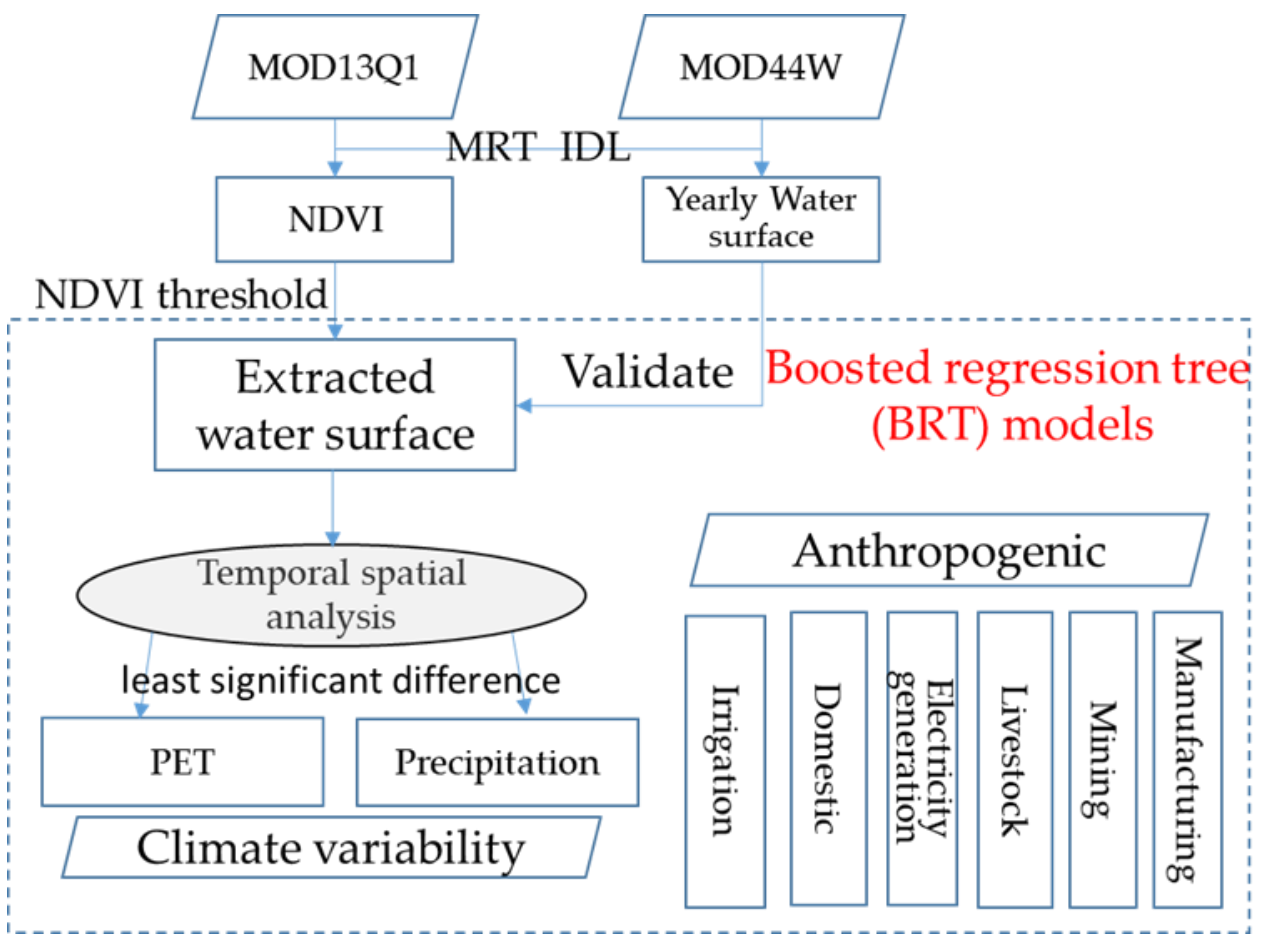

Figure 3. Schematic flow chart presenting the overall approach of the study. T MODIS Vegetation Indices 16-day L3 Global 250 m (MOD13Q1). MODIS 250 m land-water mask (MOD44W). Potential evapotranspiration (PET).

\section{Results}

\subsection{Spatial Distribution of Water Surface Area}

There appeared to be spatial and interannual changes in water surface before and after 2005, where the Nenjiang River Basin was dammed at Nierji (Figure 4a), creating a large reservoir upstream. The maximum area that surface water inundated at least once during pre-dam construction and after the dam construction was $6373 \mathrm{~km}^{2}$ and $8858 \mathrm{~km}^{2}$, respectively. The average area of the Nierii reservoir was $455 \mathrm{~km}^{2}$, accounting for $18 \%$ of the additional area. It is apparent that the river channel between the Nierji Dam and the Momoge wetland had inundation changes after the dam construction (Figure 4a). A large flood occurred in 2013, inundating much of the downstream channel below the Nierji Dam. 
However, the main channel of Nenjiang river changed little before and after the construction of the dam (Figure 4a).

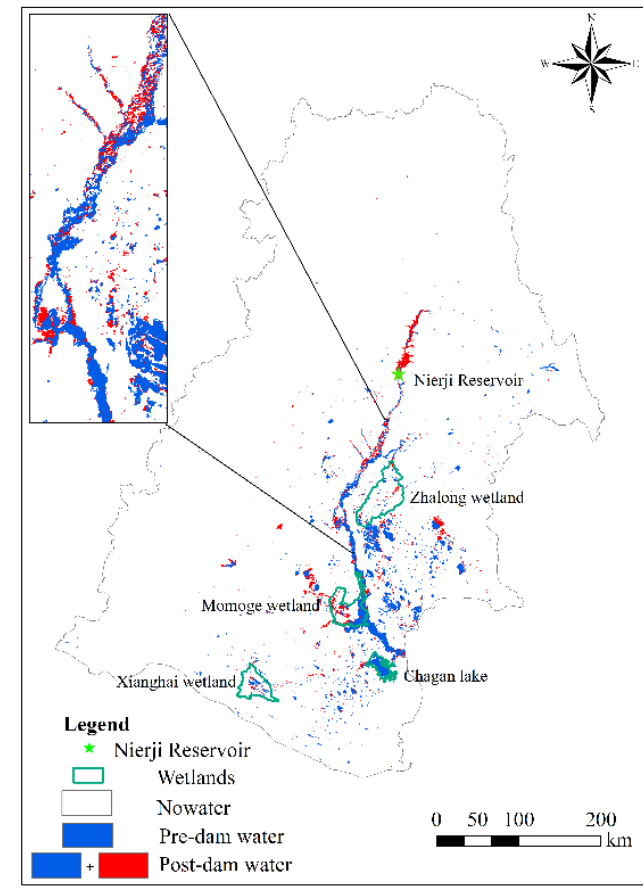

(a)

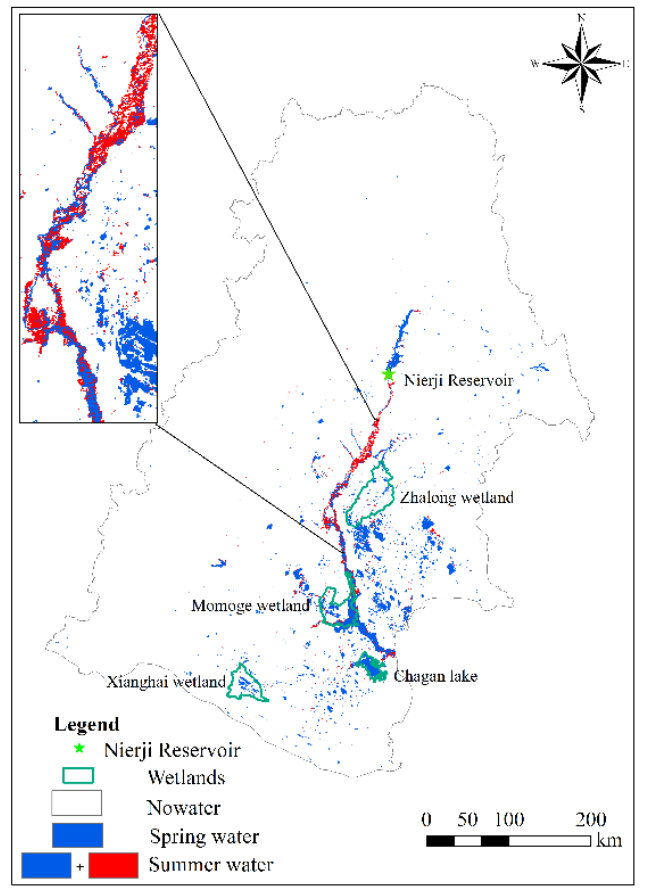

(b)

Figure 4. Distribution of open waterbody surface in the Nenjiang River Basin, Northeast China, during (a) pre-dam 2000-2004 and post-dam 2006-2018 periods and (b) in the spring and summer.

The surface area of waterbodies in the basin showed a clear seasonal fluctuation (Figure $4 \mathrm{~b}$, Table 1). The main channel of Nenjiang river was wider in the summer than in the spring, but the Zhalong lake group, Xianghai wetland, Momoge wetland, and Chagan Lake did not show a significant change in size between the two seasons. In this study, statistical analysis was conducted on water bodies with water area greater than $1 \mathrm{~km}^{2}$ in the NRB. Because the resolution of remote sensing data was $250 \mathrm{~m}$, the water area less than $1 \mathrm{~km}^{2}$ was difficult to identify, and even if identified, it was impossible to accurately determine their changes. Therefore, only the ponds, lakes, and reservoirs that were larger than $1 \mathrm{~km}^{2}$ were selected for statistical analysis. The size of most water bodies increased after the Nierji Dam was constructed, resulting in an increase of the total surface water area from $1627 \mathrm{~km}^{2}$ before 2005 to $2080 \mathrm{~km}^{2}$ in the post-dam period. The main increase was the dammed reservoir. Additionally, most waterbodies downstream of the dam increased, especially the Zhalong lake group (Table 1). The Zhalong lake group water body and Momoge wetland increased by $58 \mathrm{~km}^{2}$ and $42 \mathrm{~km}^{2}$, i.e., from $463 \mathrm{~km}^{2}$ to $521 \mathrm{~km}^{2}$ and $53 \mathrm{~km}^{2}$ to $95 \mathrm{~km}^{2}$, respectively (Table 1), while the percentage of their areal contribution to the total water surface area had little change.

In the NRB, there was a large number of reservoirs and ponds of water bodies in different sizes. During 2000-2018, the number of open water bodies greater than $1 \mathrm{~km}^{2}$ in the NRB fluctuated from 60 to 142. A wide range of surface waterbodies were concentrated in the middle and lower reaches of the NRB. Most water bodies, $57 \%$, were smaller than $5 \mathrm{~km}^{2}$, and about $21 \%$ of water bodies were within $5-10 \mathrm{~km}^{2}$ (Figure 5). 
Table 1. Mean surface areas ( \pm standard deviation) of open waterbodies in the Nenjiang River Basin (NRB), Northeast China, before and after the construction of the Nierji Dam in 2005.

\begin{tabular}{cccccc}
\hline Waterbody & Before $\left.\mathbf{( k m}^{\mathbf{2}}\right)$ & Percentage $\mathbf{( \% )}$ & After $\mathbf{( k m}^{\mathbf{2}} \mathbf{)}$ & Percentage $\mathbf{( \% )}$ & Change $\mathbf{( k m}^{\mathbf{2}} \mathbf{~}$ \\
\hline Zhalong lake & $463 \pm 66$ & 28 & $521 \pm 44$ & 25 & +50 \\
group & $301 \pm 7$ & 18 & $293 \pm 21$ & 14 & -8 \\
Chagan & $53 \pm 27$ & 3 & $95 \pm 22$ & 4 & +42 \\
Momoge & $48 \pm 5$ & 3 & $49 \pm 5$ & 2 & +1 \\
Xianghai & $762 \pm 217$ & 48 & $1122 \pm 194$ & 55 & +360 \\
Others & 1627 & 100 & 2080 & 100 & +453 \\
NRB Water area & & & & \\
\hline
\end{tabular}

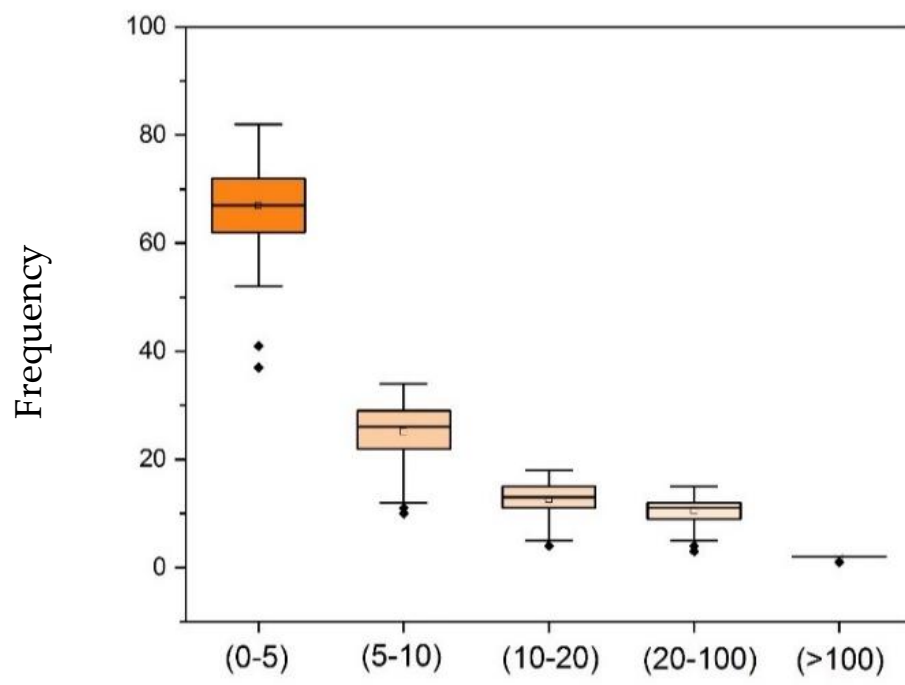

Water surface area $\left(\mathrm{km}^{2}\right)$

Figure 5. Frequency of 209 water bodies $\left(>1 \mathrm{~km}^{2}\right)$ in five size classes in the Nenjiang River Basin, Northeast China. Each boxplot illustrates the median and inter-quartile range and the whiskers indicate minimum and maximum values.

\subsection{Seasonal Change of Water Surface Area}

Water surface area in the Nenjiang River Basin varied greatly from April to September each year (Figure 6). The average total water surface area in April was about $2700 \mathrm{~km}^{2}$, followed by a decrease to approximate $1600 \mathrm{~km}^{2}$ in June and then a steady increase to about $2800 \mathrm{~km}^{2}$ in September. During July and September of 2013, rainfall was extremely higher in the region, causing large-scale flooding, with a total water surface area of greater than $5000 \mathrm{~km}^{2}$ over several months (Figure 6). The total precipitation from July to September 2013 from all meteorological stations averaged $276 \mathrm{~mm}$ in the NRB. 


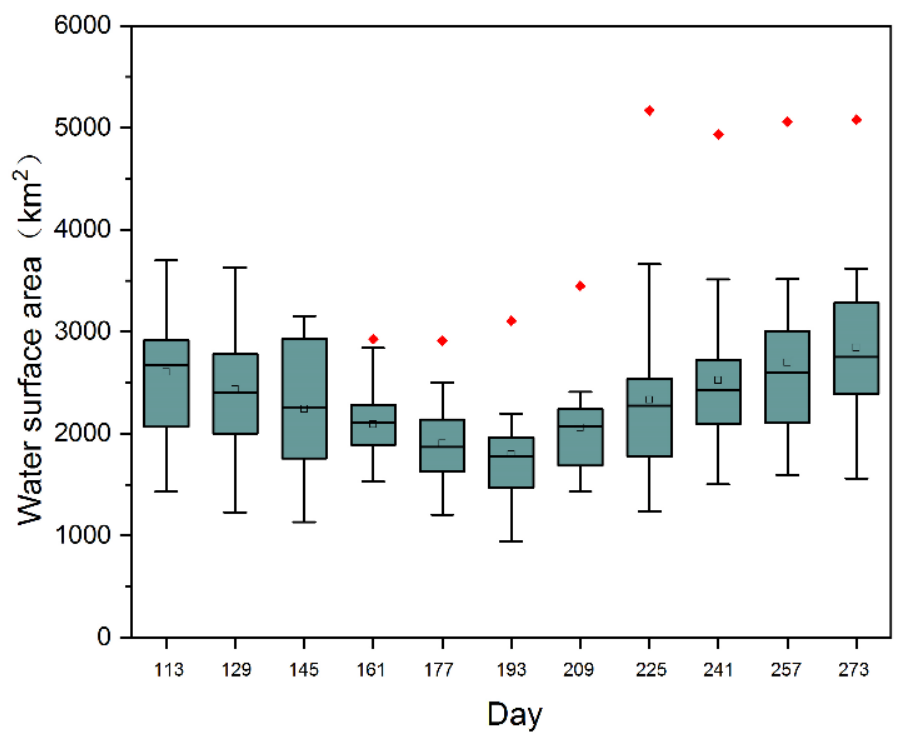

Figure 6. Changes in the total water surface area during late April and late September in the Julian day number (i.e., a non-frozen period) in the Nenjiang River Basin, Northeast China. Red solid dots denote the areas during the extreme flood event in 2013. Each boxplot illustrates the median and inter-quartile range and the whiskers indicate minimum and maximum values.

\subsection{Interannual Trend of Water Surface}

The surface area of each and all open water bodies in the Nenjiang River Basin was calculated every 16 days continuously for the period from 2000 to 2018, with a total of 209 time series of data. Over the past 19 years, there showed an increasing trend of total water surface area in the river basin (Figure 7). The largest water surface area occurred in August 2013, with a corresponding area of $5169 \mathrm{~km}^{2}$, and the smallest water surface area occurred in July 2003, with an area of $942 \mathrm{~km}^{2}$. During the 19-year study period, annual precipitation increased significantly $(p<0.05)$ and the increasing trend was more pronounced than the increasing trend of the water surface area (Figure 7).

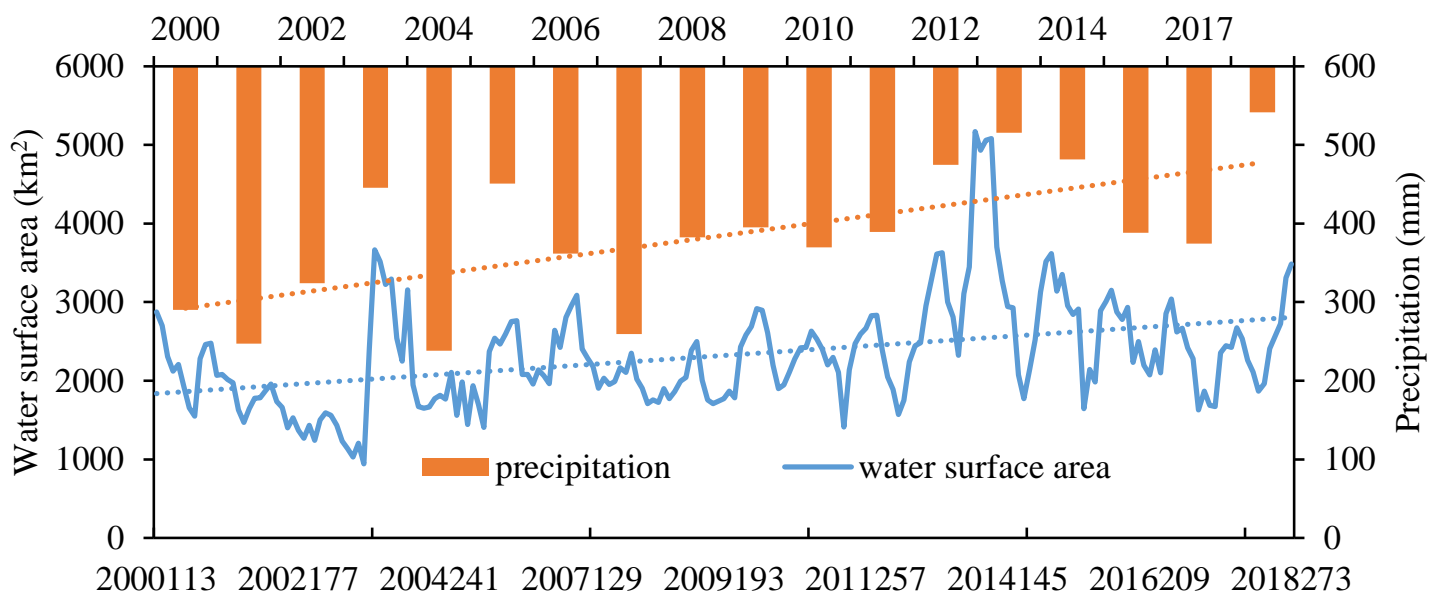

Figure 7. Time series of total open water surface area each 16 days (blue) and annual precipitation (orange) in the Nenjiang River Basin, Northeast China, from 2000 to 2018.

The largest water surface area in the Nenjiang River Basin occurred in 2013, with the maximum, median, and minimum values of 5169,3610 , and $2323 \mathrm{~km}^{2}$, which were all the highest for the 19 study years (Figure 8). The following five years (i.e., 2014-2018) also showed relatively large water surface areas with an average total waterbody area greater than the 19-year average. The average water surface 
area in 2002, 2001, 2008, 2004, and 2005 was $20 \%$ smaller than the 19-year average, corresponding to the dry summers of these five years.

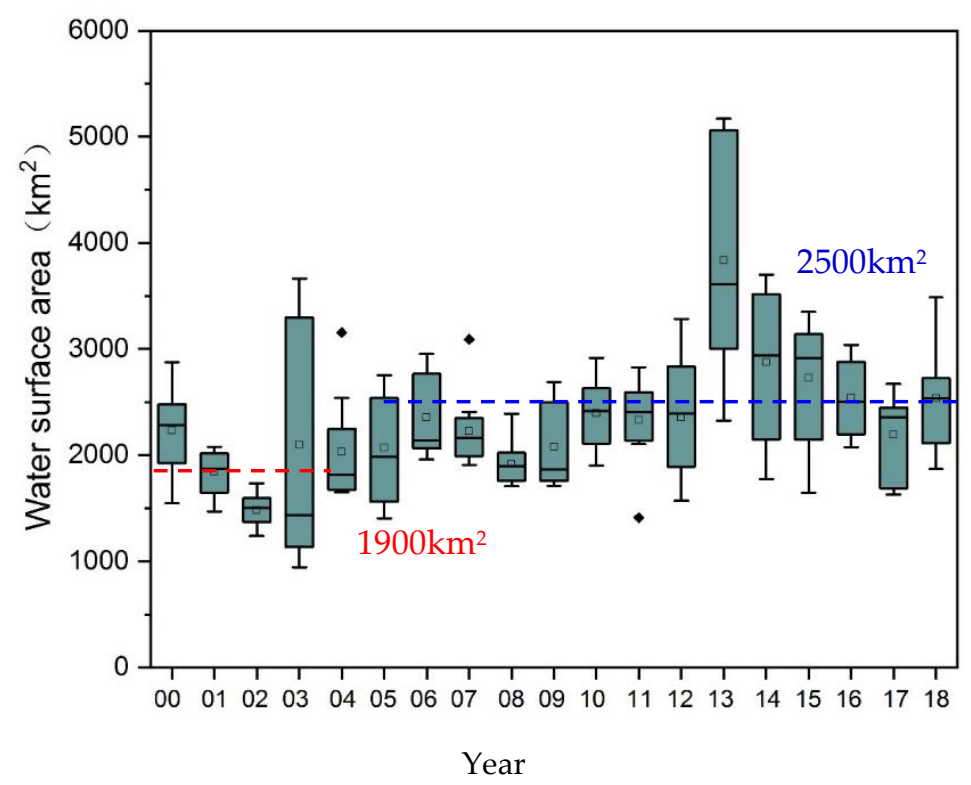

Figure 8. Annual average and variation of the total open water surface area during 2000 and 2018 in the Nenjiang River Basin, Northeast China. The red line shows the average surface area before 2005 and the blue line shows the average after 2005. Each boxplot illustrates the median and inter-quartile range and the whiskers indicate minimum and maximum values.

\subsection{Coefficient of Variation of Waterbody Surface Areas}

As shown above, the water surface areas of the open waterbodies in the Nenjiang River Basin fluctuated largely. The fluctuation appeared to be correlated with the waterbody size: The larger a waterbody was, the smaller the fluctuation was, as presented in the coefficient of variation $(\mathrm{CV})$, depicted in Figure 9. Small waterbodies (i.e., $<1 \mathrm{~km}^{2}$ ) had a wide CV, varying from $15 \%$ to $90 \%$, and large waterbodies $\left(>20 \mathrm{~km}^{2}\right)$ had comparably a much narrower CV $(10 \%$ to $35 \%)$. The relationship of fluctuation with waterbody size was negatively exponential.

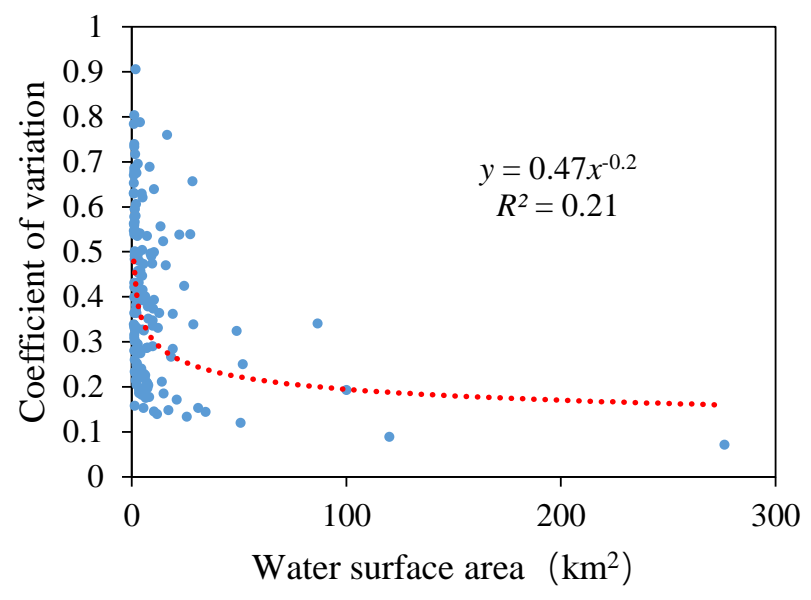

Figure 9. Coefficient of variation (\%) of lakes and reservoirs in the Nenjiang River Basin, Northeast China, in relation with their surface areas $\left(\mathrm{km}^{2}\right)$. The power function presents the numeric relationship between the coefficient of variation $(\mathrm{CV})$ and the water surface area. The Y-axis indicates that the CV shrank 100 times. 


\section{Discussion}

\subsection{Climate Effect on Water Surface Changes}

The China Blue Book on Climate Change reported a slight increasing trend in precipitation in China from 1961 to 2018 [43]. Zheng et al. [44] found that annual precipitation in the Nenjiang River Basin showed a rapid increasing trend during the post Nierji dam period. Li et al. [29] reported a steady increase of air temperature in the region from 1960 to 2010 (data not shown here), as well as an increase of precipitation from 2000 to 2010, but the average precipitation during 2000-2010 was lower than those in the previous decades. In a recent study conducted in the nearby Inner Mongolia grassland, Zhang et al. [45] reported a close association of lake area with global climate change. Some other studies $[46,47]$ also found that global climate change could have a significant effect on the area of lakes, but the change could be different in an arid or permafrost region. Most inland lakes are fed by seasonal snowmelt and rainfall, so they are sensitive to the amount of water flowing into the lakes and evaporation losses from the surface. Lake area could undergo large fluctuations because of various water inputs and outputs caused by changes in climate-related parameters; these fluctuations should be considered in future hydroclimatic and hydrological studies [45]. Generally, precipitation could be regarded as water inputs and evaporation could be regarded as water outputs.

In our study, the linear relation of the annual total water surface area (September minus April water surface area), with the precipitation amount and potential evapotranspiration, was analyzed during the non-frozen period (Figure 10). The water surface area corresponded positively (0.78) with the precipitation amount and negatively $(-0.71)$ with the PET. Among the 19 study years, maximum water surface area occurred mostly between late July and August, which is the late wet season $[48,49]$. The months with the largest water surface area did not coincide with the peak rainy months (April to June). This can be explained from spring snowmelt, which affects the water area in the NRB to a large extent [50]. From March to April, the temperature change affected the snowmelt flood, which may be the reason for the large water area in April [51]. In addition, the maximum water surface area is an accumulated effect and thus there may be a lag from the precipitation [48].
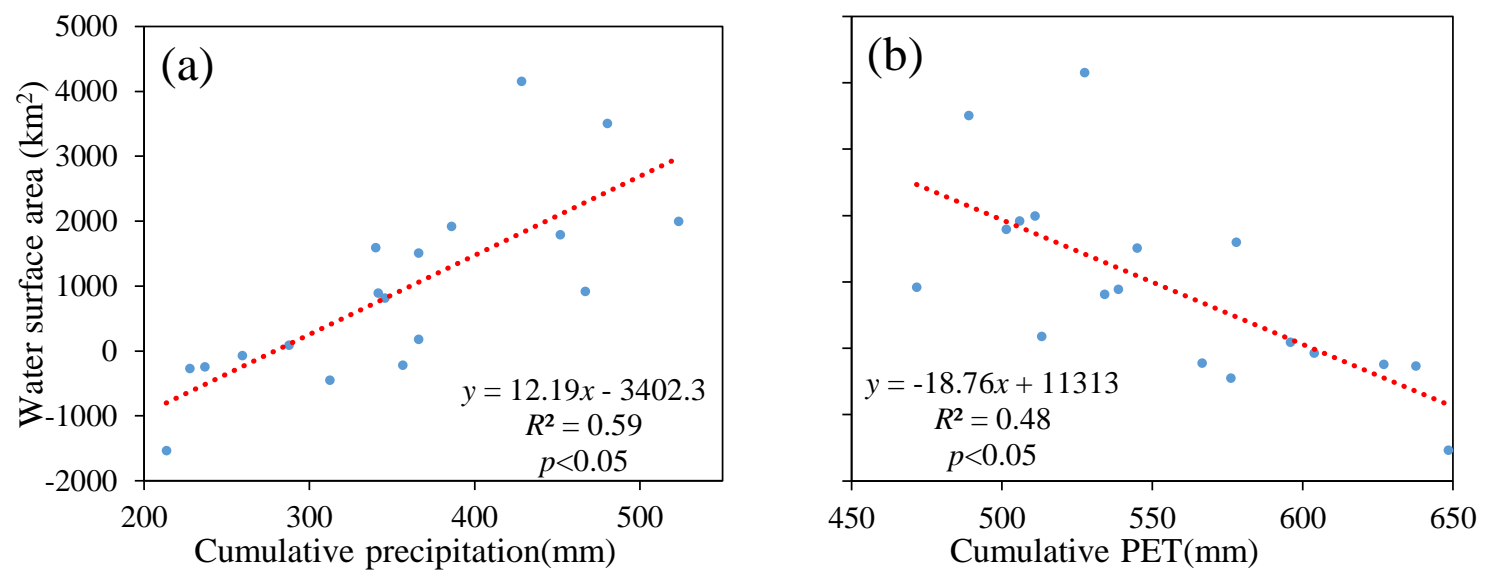

Figure 10. The relationship of changes in water surface area between April-September with (a) cumulative precipitation during the period and (b) cumulative potential evapotranspiration (PET).

The response of lake surface area to climate related variables have rarely been compared to human activity. In this study, we found that, from 2000 to 2018, the Zhalong and Momoge wetlands had the largest increase in water surface area, while the Chagan and Xianghai wetlands remained nearly unchanged (Table 1, Figure 11). This may be explained by a combined effect of climate and human activity (see next discussion section) on lake water surface area. The proximity of the Zhalong and Momoge to the river may have made the water bodies more influenced by increased precipitation. During this period, the surface area of other water bodies near the river network have also increased 
significantly (Table 1). These water bodies showed much higher seasonal variation (Figures 9 and 11), indicating their dependency in precipitation.

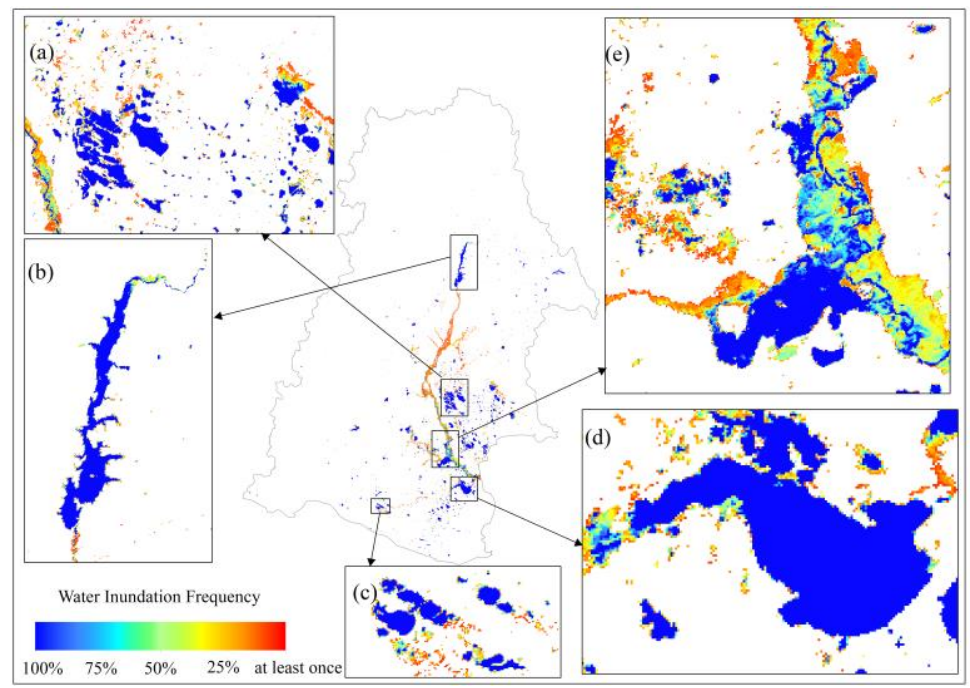

Figure 11. Nenjiang Basin 2000-2018 inundation frequency and its spatial distribution map. (a) Zhalong wetland, (b) Nierji reservoir, (c) Xianghai wetland, (d) Chagan Lake, and (e) Momoge wetland.

\subsection{Anthropogenic Impact on Water Surface Changes}

Climate was not the only factor responsible for the change in water surface area in the Nenjiang River Basin. We found a WIF of $>40 \%$ in the Zhalong wetland, which was close to the dammed reservoir, accounting for a large proportion of the whole stable water body in the river basin. Previous studies have shown that the dam has a great impact on the wetland in the basin before and after its completion, including the changes of vegetation and water resources (water surface area, flow, and water level) [52,53]. The dynamics of lakes in the basin presents a distinct spatial pattern, which is manifested by the difference in the coefficient of variation of lake areas in the NRB. This comparison shows that the water surface area of lakes, ponds, and reservoirs in the river basin is not only susceptible to local meteorological changes, but also to intensified human water regulations from both the upstream Nenjiang main stem [54] and downstream water diversion projects.

In addition to their proximity to the Nenjiang River, the water surface area changes of the Zhalong and Momoge wetlands are also affected by human activity (Figure 12). A so-called "Wetland Emergency Water Replenishment Project (WEWRP)" was carried out by diverting river water to these wetland areas [55]. Through a middle river diversion project, water from the Nenjiang River has been introduced into the WEWRP since 2001, helping maintain and/or keep sufficient water supply to the wetlands. The Momoge wetland area includes a reservoir, the Yueliang Reservoir, as well as a section of the Nenjiang River, leading to the fact that part of the water area in the Momoge wetland is directly affected by human activity. Since 2012, the Xianghai wetland has launched a "River and Lake Connection Project," which connects the river with reservoirs and bogs through artificial canals and uses rain flood resources to replenish water for the Xianghai wetland regularly [56]. This is why the Xianghai wetland shows a clear increase in water surface area after 2012. The Chagan Lake surface area appeared to be little changed because its water level was controlled by an overflow dam built at its west end. When the water level reached the upper limit, overflow occurred, and the lake regularly received discharge from rice paddies in the drainage area [56,57]. 


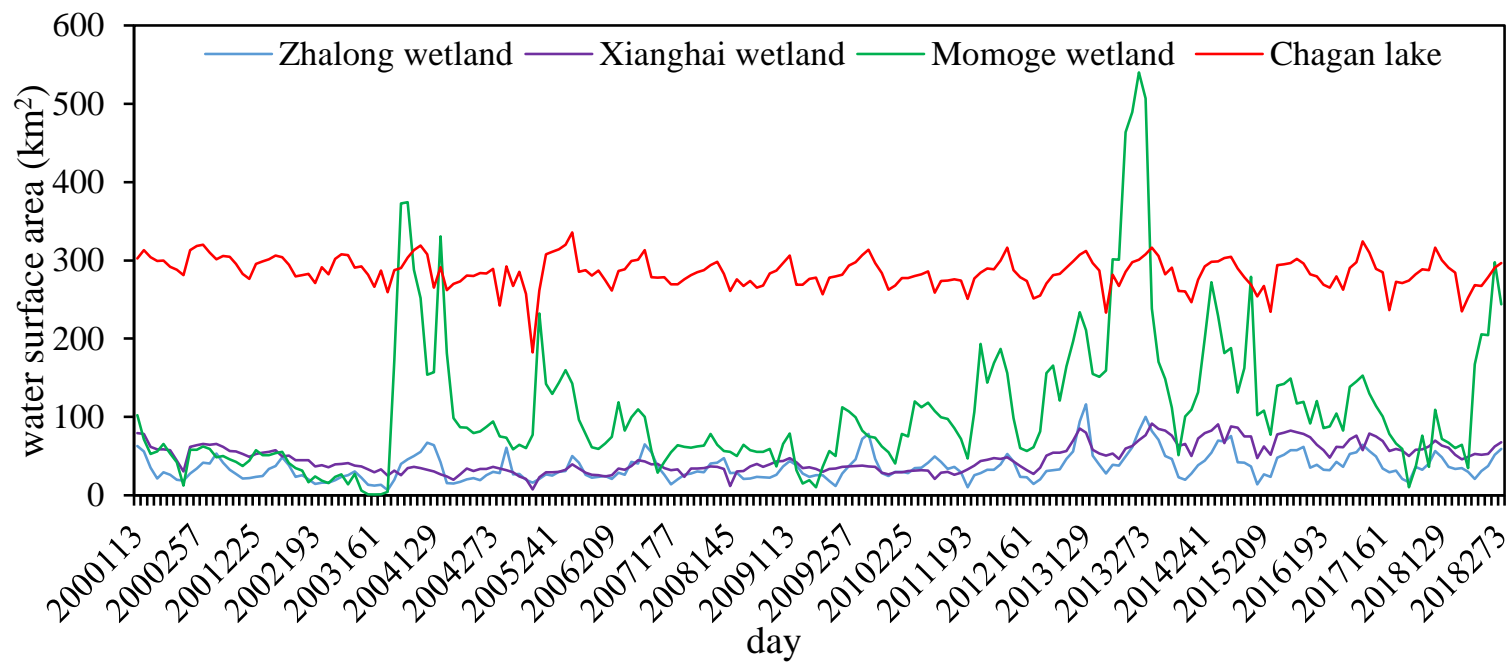

Figure 12. Fluctuation of water surface areas in Zhalong, Xinghai, Momoge, and Chagan in the Nenjiang River Basin, Northeast China, during the past 19 years.

Most of the changes in water surface area can be attributed to human activity, of which agricultural irrigation is the main factor. Previous studies reported that more than $31.77 \%$ of northeastern China's cropland is irrigated $[58,59]$. There are three main sources of irrigation water: rivers, lakes, and groundwater [60]. Irrigation water is mainly used from May through July. Groundwater is a key component for water resources for the Songnen Plain, an important agricultural basement in China, which includes the lower NRB. Groundwater provides a reliable source to sustain agricultural production. Agriculture, the main consumer of water resources, generally consumes more than $70 \%$ of all groundwater exploitation [61]. However, the groundwater irrigation in the Songnen Plain is exploited, and the surface water irrigation recharge is 3.52\% [62]. This is the main reason why, from late May to early July, the water surface area keeps descending in the NRB, and receding farmland caused the surface water area to increase in September (Figure 6).

The natural ponds and lakes seem to have a more regular variation than the artificial reservoirs. Coefficient values of two power functions indicated that the natural ponds and lakes seem to have a more regular variation than the artificial reservoirs (Figure 13). This may reflect that the man-made reservoirs are frequently used for irrigation or other agricultural uses. On the other site, natural bubble marshes and lakes are less affected by human control, and their coefficient of variation is more closely correlated with water surface area.
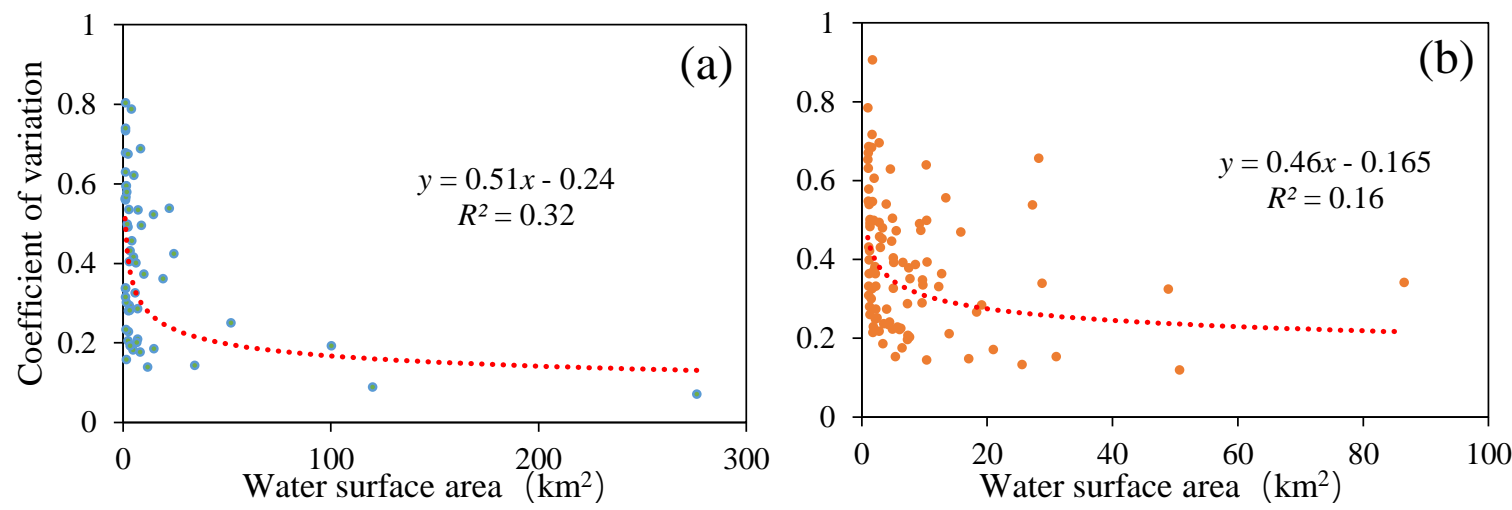

Figure 13. Coefficient of variation in the relationship with (a) water surface area of ponds and lakes and (b) reservoirs. Reservoirs were identified in the Google Earth map. The power function shows the relationship between $\mathrm{CV}$ and water surface area in the types of water bodies. the $Y$-axis indicates that the CV shrank 100 times. 


\subsection{Contribution of Climate Variability and Anthropogenic to Water Surface Area in NRB}

The BRT modeling results show that rainfall, evaporation, and irrigation are the main driving factors affecting the change in water surface area. Comparably, the combined contribution of all human activities is smaller than that of climate factors. However, irrigation appeared to be the driving force for water area change from May to June (Table 2). The two contributing factors, precipitation and irrigation, fluctuated significantly during the summer season. The contribution of irrigation showed a decreasing trend, while precipitation showed an increasing trend. When combined, the two climate factors (precipitation and evapotranspiration) contributed more (57\%) than the five human factors (irrigation, livestock, mining, domestic, and manufacturing) to the water surface area change in this high latitude river basin during the past 19 years.

Table 2. Summary of the relative contributions (\%) of predictor variables for a boosted regression tree model developed with cross validation on water surface area data using tree complexity of 5 and learning rate of $0 \cdot 005$.

\begin{tabular}{ccccccc}
\hline & \multicolumn{7}{c}{ Relative Contribution (\%) } \\
\cline { 2 - 7 } Predictor & Yearly & May & June & July & August & September \\
\hline Irrigation & 20 & 31 & 34 & 26 & 23 & 17 \\
Livestock & 4 & 3 & 4 & 4 & 5 & 7 \\
Mining & 6 & 5 & 7 & 4 & 3 & 6 \\
Domestic & 8 & 5 & 4 & 5 & 6 & 5 \\
Manufacturing & 5 & 3 & 4 & 6 & 4 & 8 \\
Potential evapotranspiration & 26 & 28 & 24 & 30 & 27 & 28 \\
Precipitation & 31 & 25 & 23 & 25 & 32 & 29 \\
Global climate change & 57 & 53 & 47 & 55 & 59 & 57 \\
Anthropogenic & 43 & 47 & 53 & 45 & 41 & 43 \\
\hline
\end{tabular}

\section{Conclusions}

This study is one of the few assessments of long-term changes in inland water surface area at a large river basin scale in high-time resolution. The study utilized time-series of MOD13Q1 images taken during 2000-2018 in China's high latitude NRB and analyzed the dynamics of water body surface areas in the river basin during the non-frozen season from April to September. We applied a combination of NDVI threshold algorithms to quantify the total areas of 209 surface water bodies that were greater than $1 \mathrm{~km}^{2}$ in size. We found that the total water surface area in the river basin has increased in the past 19 years, due to both precipitation increase and human activity. Snowmelt in spring results in a large water surface area in May, followed by a decline in June and July, because of agricultural uses (e.g., irrigation and reservoir refilling). The monsoon weather in summer leads to a gradual increase in water surface area in early August, accompanying discharge from rice paddies. Our study demonstrates that inland water areas are strongly affected by both climate variability and human activity. In general, global climate change contributes more (57\%) to water surface area change than anthropogenic activities (43\%), but anthropogenic activities, including irrigation water, have the greatest impact on water changes from May to July every year. This study also demonstrates that the individual contribution of climate variability and human activity on water surface area change can be quantified with a combination of remote sensing data, climate records, and human water consumption. However, these findings are based on only one river basin, and additional studies are necessary to shed light on future change in water surface area across the high latitude region.

Author Contributions: G.Z., Y.J.X., and L.C. conceived the idea of the study; L.C. carried out data analysis; L.C. wrote the first manuscript draft; G.Z. supervised the research project and contributed to oversight of the data collection; Y.J.X. contributed critical conceptual review and manuscript revisions at all stages; Y.W. reviewed and edited this manuscript; Z.G. supported the weather data; S.C. and H.Y. preprocessed the data. All authors have read and agreed to the published version of the manuscript. 
Funding: This research was supported by the National Key R\&D Program of China (Grant: 2017YFC0406003), the National Natural Science Foundation of China (Grant: 41877160), the Featured Institute Project, the Northeast Institute of Geography and Agroecology, and the Chinese Academy of Sciences (Grant No. IGA-135-05). During the preparation of the manuscript, Y.J.X. received funding support from a US Department of Agriculture Hatch Fund project (project number: LAB94230). The statements, findings, and conclusions are those of the authors and do not necessarily reflect the views of the funding agencies.

Acknowledgments: We are grateful to the Associate Editor and three anonymous reviewers for their careful reading of our manuscript and their constructive remarks.

Conflicts of Interest: The authors declare no conflict of interest.

\section{References}

1. Huang, C.; Chen, Y.; Zhang, S.; Wu, J. Detecting, Extracting, and Monitoring Surface Water From Space Using Optical Sensors: A Review. Rev. Geophys. 2018, 56, 333-360. [CrossRef]

2. Downing, J.A.; Prairie, Y.T.; Cole, J.J.; Duarte, C.M.; Tranvik, L.J.; Striegl, R.G.; McDowell, W.H.; Kortelainen, P.; Caraco, N.F.; Melack, J.M. The global abundance and size distribution of lakes, ponds, and impoundments. Limnol. Oceanogr. 2006, 51, 2388-2397. [CrossRef]

3. Prigent, C.; Papa, F.; Aires, F.; Rossow, W.B.; Matthews, E. Global inundation dynamics inferred from multiple satellite observations, 1993-2000. J. Geophys. Res. Space Phys. 2007, 112. [CrossRef]

4. Vörösmarty, C.J. Global Water Resources: Vulnerability from Climate Change and Population Growth. Sci. 2000, 289, 284-288. [CrossRef]

5. Sobek, S.; Tranvik, L.J.; Cole, J.J. Temperature independence of carbon dioxide supersaturation in global lakes. Glob. Biogeochem. Cycles 2005, 19, 10. [CrossRef]

6. Lapierre, J.F.; del Giorgio, P.A. Geographical and environmental drivers of regional differences in the lake pCO2 versus DOC relationship across northern landscapes. J. Geophys. Res.-Biogeosci. 2012, 117, G03015. [CrossRef]

7. Raymond, P.A.; Hartmann, J.; Lauerwald, R.; Sobek, S.; McDonald, C.; Hoover, M.; Butman, D.; Striegl, R.; Mayorga, E.; Humborg, C.; et al. Global carbon dioxide emissions from inland waters. Nat. 2013, 503, 355-359. [CrossRef]

8. $\mathrm{Xu}, \mathrm{Y} . J . ; \mathrm{Xu}, \mathrm{Z}$; Y Yang, R. Rapid daily change in surface water $\mathrm{pCO} 2$ and $\mathrm{CO} 2$ evasion: A case study in a subtropical eutrophic lake in Southern USA. J. Hydrol. 2019, 570, 486-494. [CrossRef]

9. Veldkamp, T.; Wada, Y.; Aerts, J.; Doll, P.; Gosling, S.N.; Liu, J.; Masaki, Y.; Oki, T.; Ostberg, S.; Pokhrel, Y.; et al. Water scarcity hotspots travel downstream due to human interventions in the 20th and 21st century. Nat. Commun. 2017, 8, 15697. [CrossRef]

10. Feng, X.; Zhang, G.; Yin, X. Hydrological Responses to Climate Change in Nenjiang River Basin, Northeastern China. Water Resour. Manag. 2010, 25, 677-689. [CrossRef]

11. Pekel, J.-F.; Cottam, A.; Gorelick, N.; Belward, A.S. High-resolution mapping of global surface water and its long-term changes. Nat. 2016, 540, 418-422. [CrossRef]

12. Deng, Y.; Jiang, W.; Tang, Z.; Li, J.; Lv, J.; Chen, Z.; Jia, K. Spatio-Temporal Change of Lake Water Extent in Wuhan Urban Agglomeration Based on Landsat Images from 1987 to 2015. Remote Sens. 2017, 9, 270. [CrossRef]

13. Song, C.; Huang, B.; Richards, K.; Ke, L.; Phan, V.H. Accelerated lake expansion on the Tibetan Plateau in the 2000s: Induced by glacial melting or other processes? Water Resour. Res. 2014, 50, 3170-3186. [CrossRef]

14. Rao, P.; Jiang, W.; Hou, Y.; Chen, Z.; Jia, K. Dynamic Change Analysis of Surface Water in the Yangtze River Basin Based on MODIS Products. Remote Sens. 2018, 10, 1025. [CrossRef]

15. Palmer, S.C.; Kutser, T.; Hunter, P.D. Remote sensing of inland waters: Challenges, progress and future directions. Remote Sens. Environ. 2015, 157, 1-8. [CrossRef]

16. Xing, L.; Tang, X.; Wang, H.; Fan, W.; Wang, G. Monitoring monthly surface water dynamics of Dongting Lake using Sentinal-1 data at $10 \mathrm{~m}$. PeerJ 2018, 6, e4992. [CrossRef]

17. Sánchez, N.; González-Zamora, Á.; Piles, M.; Martínez-Fernández, J. A New Soil Moisture Agricultural Drought Index (SMADI) Integrating MODIS and SMOS Products: A Case of Study over the Iberian Peninsula. Remote Sens. 2016, 8, 287. 
18. Che, X.; Feng, M.; Sexton, J.; Channan, S.; Sun, Q.; Ying, Q.; Liu, J.; Wang, Y. Landsat-Based Estimation of Seasonal Water Cover and Change in Arid and Semi-Arid Central Asia (2000-2015). Remote Sens. 2019, 11, 1323. [CrossRef]

19. Carroll, M.; Townshend, J.; DiMiceli, C.; Noojipady, P.; Sohlberg, R. A new global raster water mask at $250 \mathrm{~m}$ resolution. Int. J. Digit. Earth 2009, 2, 291-308. [CrossRef]

20. Yamazaki, D.; Trigg, M.A.; Ikeshima, D. Development of a global 90m water body map using multi-temporal Landsat images. Remote Sens. Environ. 2015, 171, 337-351. [CrossRef]

21. Lu, S.; Ma, J.; Ma, X.; Tang, H.; Zhao, H.; Baig, M.H.A. Time series of the Inland Surface Water Dataset in China (ISWDC) for 2000-2016 derived from MODIS archives. Earth Syst. Sci. Data 2019, 11, 1099-1108. [CrossRef]

22. Zhang, G.; Li, J.; Zheng, G. Lake-area mapping in the Tibetan Plateau: An evaluation of data and methods. Int. J. Remote Sens. 2016, 38, 742-772. [CrossRef]

23. Barnett, T.P.; Adam, J.C.; Lettenmaier, D.P. Potential impacts of a warming climate on water availability in 420 snow-dominated regions. Nature 2005, 438, 303-309. [CrossRef]

24. Laudon, H.; Spence, C.; Buttle, J.; Carey, S.K.; McDonnell, J.J.; McNamara, J.P.; Soulsby, C.; Tetzlaff, D. Save northern high-latitude catchments. Nat. Geosci. 2017, 10, 324-325. [CrossRef]

25. Moore, G.W.K. The December 2015 North Pole Warming Event and the Increasing Occurrence of Such Events. Sci. Rep. 2016, 6, 39084. [CrossRef]

26. Xia, J.; Zhang, L.; Liu, C.; Yu, J. Towards better water security in North China. Water Resour. Manag. 2007, 21, 233-247. [CrossRef]

27. Wang, Z.; Song, K.; Ma, W.; Ren, C.; Zhang, B.; Liu, D.; Chen, J.M.; Song, C. Loss and Fragmentation of Marshes in the Sanjiang Plain, Northeast China, 1954-2005. Wetl. 2011, 31, 945-954. [CrossRef]

28. Li, F.; Zhang, G.; Xu, Y.J. Separating the Impacts of Climate Variation and Human Activities on Runoff in the Songhua River Basin, Northeast China. Water 2014, 6, 3320-3338. [CrossRef]

29. Li, F.; Zhang, G.; Xu, Y.J. Spatiotemporal variability of climate and streamflow in the Songhua River Basin, northeast China. J. Hydrol. 2014, 514, 53-64. [CrossRef]

30. Wu, Y.; Zhang, G.; Shen, H.; Xu, Y.J. Nonlinear response of streamflow to climate change in the headwater areas of Nenjiang River Basin, Northeast China. Water 2018, 10, 294. [CrossRef]

31. Han, M.; Sun, Y.; Xu, S. Characteristics and driving factors of marsh changes in Zhalong wetland of China. Environ. Monit. Assess. 2006, 127, 363-381. [CrossRef]

32. The Level-1 and Atmosphere Archive \& Distribution System (LAADS) Distributed Active Archive Center (DAAC), NASA. Available online: https://ladsweb.modaps.eosdis.nasa.gov (accessed on 30 January 2020).

33. China Meteorological Data Sharing System. Available online: http://data.cma.cn/ (accessed on 30 January 2020).

34. Monteith, J.L. Evaporation and environment. Symp. Soc. Exp. Boil. 1965, 19, 205.

35. Huang, Z.; Hejazi, M.; Li, X.; Tang, Q.; Vernon, C.; Leng, G.; Liu, Y.; Döll, P.; Eisner, S.; Gerten, D.; et al. Reconstruction of global gridded monthly sectoral water withdrawals for 1971-2010 and analysis of their spatiotemporal patterns. Hydrol. Earth Syst. Sci. 2018, 22, 2117-2133. [CrossRef]

36. Pal, S.; Talukdar, S. Drivers of vulnerability to wetlands in Punarbhaba river basin of India-Bangladesh. Ecol. Indic. 2018, 93, 612-626. [CrossRef]

37. Li, Z.; Feng, Y.; Dessay, N.; Delaitre, E.; Gurgel, H.; Gong, P. Continuous Monitoring of the Spatio-Temporal Patterns of Surface Water in Response to Land Use and Land Cover Types in a Mediterranean Lagoon Complex. Remote Sens. 2019, 11, 1425. [CrossRef]

38. Han, Z.; Long, D.; Fang, Y.; Hou, A.; Hong, Y. Impacts of climate change and human activities on the flow regime of the dammed Lancang River in Southwest China. J. Hydrol. 2019, 570, 96-105. [CrossRef]

39. Fisher, R.A. The design of experiments, 8th ed.; Oliver \& Boyd: London, UK, 1966.

40. Elith, J.; Leathwick, J.R.; Hastie, T. A working guide to boosted regression trees. J. Anim. Ecol. 2008, 77, 802-813. [CrossRef]

41. Radinger, J.; Alcaraz-Hernández, J.D.; Garcia-Berthou, E. Environmental and spatial correlates of hydrologic alteration in a large Mediterranean river catchment. Sci. Total. Environ. 2018, 639, 1138-1147. [CrossRef]

42. Friedman, J.H. Greedy function approximation: A gradient boosting machine. Ann. Statist. 2001, 29, 1189-1232. [CrossRef] 
43. Ying, L.; Huai-liang, C.; Hong-wei, T.; Wei-dong, Y. Estimation of winter wheat yield based on coupling remote sensing information and WheatSM model. Chin. J. Ecol. 2019, 38, 2258-2264. (in Chinese).

44. Zheng, Y.; Zhang, G.; Wu, Y.; Xu, Y.J.; Dai, C. Dam Effects on Downstream Riparian Wetlands: The Nenjiang River, Northeast China. Water 2019, 11, 2038. [CrossRef]

45. Zhang, Y.; Liang, W.; Liao, Z.; Han, Z.; Xu, X.; Jiao, R.; Liu, H. Effects of climate change on lake area and vegetation cover over the past 55 years in Northeast Inner Mongolia grassland, China. Theor. Appl. Clim. 2019, 138, 13-25. [CrossRef]

46. Bai, J.; Chen, X.; Li, J.; Yang, L.; Fang, H. Changes in the area of inland lakes in arid regions of central Asia during the past 30 years. Environ. Monit. Assess. 2010, 178, 247-256. [CrossRef]

47. Karlsson, J.M.; Lyon, S.W.; Destouni, G. Temporal Behavior of Lake Size-Distribution in a Thawing Permafrost Landscape in Northwestern Siberia. Remote Sens. 2014, 6, 621-636. [CrossRef]

48. Feng, L.; Hu, C.; Chen, X.; Cai, X.; Tian, L.; Gan, W. Assessment of inundation changes of Poyang Lake using MODIS observations between 2000 and 2010. Remote Sens. Environ. 2012, 121, 80-92. [CrossRef]

49. Wang, J.; Sheng, Y.; Tong, T.S.D. Monitoring decadal lake dynamics across the Yangtze Basin downstream of Three Gorges Dam. Remote Sens. Environ. 2014, 152, 251-269. [CrossRef]

50. Mei, X.; Yan, F.; Qi-Wei, S. Analysis of snowmelt runoff model in Nenjiang river basin. Water Resour. Hydropower Northeast. China 2014, 32, 33-35. (In Chinese)

51. Shuping, D.; Cheng, Y.; Yankun, S. Analysis on Meteorological Conditions of Snowmelt Flood in Yakeshi in Last 30 Years. Chinese Agric. Sci. Bull. 2012, 28, 306-310. (In Chinese)

52. Feng, L.; Han, X.; Hu, C.; Chen, X. Four decades of wetland changes of the largest freshwater lake in China: Possible linkage to the Three Gorges Dam? Remote Sens. Environ. 2016, 176, 43-55. [CrossRef]

53. Pal, S.; Saha, T.K. Identifying dam-induced wetland changes using an inundation frequency approach: The case of the Atreyee River basin of Indo-Bangladesh. Ecohydrol. Hydrobiol. 2018, 18, 66-81. [CrossRef]

54. Guo, H.; Hu, Q.; Zhang, Q.; Feng, S. Effects of the Three Gorges Dam on Yangtze River flow and river interaction with Poyang Lake, China: 2003-2008. J. Hydrol. 2012, 416, 19-27. [CrossRef]

55. Wang, Y.L.; Zhou, J.L.; Duan, H.Y.; Liu, M.; Wang, X.E. A study on ecological compensation mechanism of Xianghai wetlands water supplement. In Proceedings of the 2011 International Conference on Electrical and Control Engineering; Institute of Electrical and Electronics Engineers (IEEE), Yichang, China, 16-18 September 2011; pp. 5706-5709.

56. Guo, W.; Wang, Y.; Shi, J.; Zhao, X.; Xie, Y. Sediment information on natural and anthropogenic-induced change of connected water systems in Chagan Lake, North China. Environ. Geochem. Heal. 2019, 1-14. [CrossRef] [PubMed]

57. Liu, X.; Zhang, G.; Xu, Y.J.; Wu, Y.; Liu, Y.; Zhang, H. Assessment of water quality of best water management practices in lake adjacent to the high-latitude agricultural areas, China. Environ. Sci. Pollut. Res. 2019, 1-12. [CrossRef] [PubMed]

58. Wang, M.; Du, L.; Ke, Y.; Huang, M.; Zhang, J.; Zhao, Y.; Li, X.; Gong, H. Impact of Climate Variabilities and Human Activities on Surface Water Extents in Reservoirs of Yongding River Basin, China, from 1985 to 2016 Based on Landsat Observations and Time Series Analysis. Remote Sens. 2019, 11, 560. [CrossRef]

59. Wu, P.; Jin, J.; Zhao, X. Impact of climate change and irrigation technology advancement on agricultural water use in China. Clim. Chang. 2010, 100, 797-805. [CrossRef]

60. Xiang, K.; Ma, M.; Liu, W.; Dong, J.; Zhu, X.; Yuan, W. Mapping Irrigated Areas of Northeast China in Comparison to Natural Vegetation. Remote Sens. 2019, 11, 825. [CrossRef]

61. Bian, J.; Nie, S.; Wang, R.; Wan, H.; Liu, C. Hydrochemical characteristics and quality assessment of groundwater for irrigation use in central and eastern Songnen Plain, Northeast China. Environ. Monit. Assess. 2018, 190, 382. [CrossRef]

62. Zhi, S.C.; Yu, L.X. Water resources' distribution characteristics, development potential and its utilizing countermeasures in the 21st century in Songnen Basin. J. Nat. Resour. 2001, 4, 58-63. (In Chinese)

(C) 2020 by the authors. Licensee MDPI, Basel, Switzerland. This article is an open access article distributed under the terms and conditions of the Creative Commons Attribution (CC BY) license (http://creativecommons.org/licenses/by/4.0/). 